\title{
The Question of Applicability: EU Law or International Law in Nord Stream 2
}

\author{
Paul Gragl \\ Department of Law, Queen Mary, University of London, London, \\ United Kingdom \\ $<$ p.gragl@qmul.ac.uk>
}

\begin{abstract}
Seeing that a bilateral agreement between the EU and Russia on the Nord Stream 2 pipeline project is highly unlikely to be concluded due to political considerations, this paper enquires which existing legal regime is applicable to the governing of this pipeline, especially in order to guarantee solidarity and security within the EU energy market through third-party access and unbundling requirements. The question is whether EU law in general (which the Council denies) or international law applies, and if the latter, which specific regime(s): the Energy Charter Treaty, wто law, the law of the sea, or a combination of regimes? Lastly, this paper also investigates whether and to what extent these international law regimes might guarantee the same solidarity and energy security standards as EU law.
\end{abstract}

\section{Keywords}

Nord Stream 2 - pipelines - third-party access - unbundling - international energy law

\section{$1 \quad$ Introduction}

The Nord Stream 2 project, currently being built by the Russian governmentowned Gazprom along with a consortium of European energy companies, is designed to transport natural gas directly from Russia to Germany - and thereby the European Union (EU) - under the Baltic Sea. This project promises not

1 Priv-Doz. MMag Dr Paul Gragl, Reader in Public International Law and Theory.

(C) KONINKLIJKE BRILL NV, LEIDEN, 2019| DOI:10.1163/15730352-04402001 
only to increase the transit of natural gas from Russia to the EU by doubling the capacity of the existing Nord Stream 1 pipeline, but also to strengthen Germany's role as a regional gas transit and hub. ${ }^{2}$ Concurrently, by circumventing any other transit countries, such as Ukraine, political disputes with these countries that could potentially impact upon transit reliability, can also be avoided. Nonetheless, Nord Stream 2 remains one of the most controversial projects in EU energy policy. Moreover, due to its geopolitical and legal effects, ${ }^{3}$ its promising benefits could eventually turn out to be a toxic gift. In particular Poland and the Baltic States, but also the United States, are resisting the construction of this gas pipeline, as it will allow Russia to bypass traditional transit countries and thus to attempt to exert political influence on them by threatening their gas supply without affecting supplies to Western Europe. ${ }^{4}$ This prospect of Russia utilizing its gas supply as a 'weapon'5 sheds a completely different light on the Nord Stream 2 project and its potential to detrimentally affect the EU's declared long-term strategy to diversify its gas suppliers, as being solely dependent on Russian gas cannot be in the EU's interest. Accordingly, it remains doubtful whether Nord Stream 2 is, as its backers insist, merely 'business pure and simple'. ${ }^{6}$

As a lawyer, it is not my intention to further engage with these (geo-)political questions here, especially bearing in mind my lack of training in political science. My plan is rather to examine the question 'what is the law, pure and simple', applicable to the Nord Stream 2 project, and why? Yet at the same time, this endeavor presents itself as extremely intricate right from the outset, as energy law is inextricably linked to energy policy, ${ }^{7}$ and it thus seems that law and politics cannot be neatly separated here (if that is even possible at all in any other context either). This is also true for the divergent views of the project

2 Harald Hecking, Simon Schulte, Adnan Vatansever, and Slawomir Raszewski, "Final Report: Options for Gas Supply Diversification for the EU and Germany in the Next Two Decades", Report by the ewi Energy Research \& Scenarios GmbH and the European Centre for Energy and Resource Security (EUCERS), October 2016, 49.

3 Slawomir Raszewski, "Russian Energy Projects and the Global Climate, Geopolitics, and Development Conundrum", in Rafael Leal-Arcas and Jan Wouters (eds), Research Handbook on EU Energy Law and Policy (Edward Elgar, Cheltenham, 2017) 229.

4 Oleg Nikiforov and Gunter-E Hackemesser, "Nord Stream", in Oleg Nikiforov and Gunter-E Hackemesser (eds), Die Schlacht um Europas Gasmarkt (Springer, Wiesbaden, 2018) 226-227.

5 Ruven Fleming, "A Legal Perspective on Gas Solidarity", 124(1) Energy Policy (2019), 102-110, at 102.

6 Edward Lucas, The New Cold War: Putin's Threat to Russia and the West ( $2^{\text {nd }}$ edn; Bloomsbury, London, 2014) 218.

7 Kim Talus, EU Energy Law and Policy: A Critical Account (oup, Oxford, 2013) 6. 
within the EU itself and among the Member States, first and foremost due to EU energy policy being a shared competence between the Union and the Member States, ${ }^{8}$ thereby giving rise to enduring tensions among the Member States and between the Member States and the EU institutions. ${ }^{9}$ Furthermore, it is also true that choosing (and subsequently applying) one particular legal basis reflects a certain political choice, ${ }^{10}$ as some legal provisions might be politically more opportune than others.

Having said that, I nevertheless try to examine the question at hand, namely, what the relevant law is as well as its applicability, as best as possible from a legal-positivist viewpoint; concurrently, I also accept that the content of the law is always shaped by political considerations and thus to be taken addito salis grano. ${ }^{11}$ Seeing that there is no bilateral international agreement between the EU and Russia governing the Nord Stream 2 project (and that such an agreement is highly unlikely to be concluded in the present-day political climate), again, the questions I attempt to answer in this contribution are: which existing legal regime is applicable to Nord Stream 2? Is it EU law or international law and, if the latter, which specific regime and can this regime also guarantee specific aspects that are crucial elements of EU energy law (above all, solidarity, the functioning of the internal energy market, and security of gas supply qua unbundling and third-party access) ${ }^{12}$ It is this last sub-question, namely whether international law can safeguard the same standards as EU law, in case it does not apply, which contains the predominant political core question in terms of legal applicability. For if a leaked European Commission document from $2015^{13}$ is to be trusted, then Gazprom is quite eager to abuse its dominant

8 See Arts 2(2) and 4(2)(i) TFEU.

$9 \quad$ Nicole Herweg, "European Energy Policy", in Nikolaos Zahariadis and Lauri Buonanno (eds), The Routledge Handbook of European Public Policy (Routledge, Abingdon, 2018) 262.

10 See especially in the context of EU law, Merijn Chamon, "The Dividing Line between Delegated and Implementing Acts, Part Two: The Court of Justice Settles the Issue in Commission v Parliament and Council (Visa Reciprocity)", 52(6) CMLR (2015) 1617-1633, at 1633; Annegret Engel, The Choice of Legal Basis for Acts of the European Union (Springer, Cham, 2018) 94 .

11 This is a view which is also in line with a strictly 'pure' view of the law; see Hans Kelsen, Pure Theory of Law (2 ${ }^{\text {nd }}$ edn; University of California Press, Berkeley, 1967) 53; Hans Kelsen, General Theory of Law and State (Harvard University Press, Cambridge, Massachusetts, 1945) 438-439.

12 I will further explain and analyze these aspects in section 2.

13 European Commission, "Statement of Objections; Case AT.39816 - Upstream Gas Supplies in Central and Eastern Europe”, undated 2015 draft document, available at <http:// biznesalert.com/leak-ec-knows-gazprom-abuses-there-will-be-no-consequences/>. 
position on the EU gas market to try to segment its internal market along national borders, so that it could impose unfair pricing. And ultimately, it is the above-mentioned essential elements of EU energy law, that is, unbundling and third-party access, that could prevent such a segmentation of the Union's internal market by Gazprom (and therewith the Russian Federation).

To this end, I discuss, in section 2, first these elements of EU energy law, and subsequently whether EU law is applicable to Nord Stream 2 or not. Section 3 then focuses on the potential applicability of public international law to this project, starting with the Energy Charter Treaty, the relevant rules of the World Trade Organization (WTO), and lastly the law of the sea (which might allow for indirect application of EU law).

\subsection{The Fundamental Principles of European Union Energy Law}

With the entry into force of the Lisbon Treaty in December 2009, a specific legal basis for the energy sector was established in primary EU law for the first time. This legal basis is enshrined in Article 194(1) TFEU which states that the Union's energy policy, in a spirit of solidarity, aims, inter alia, to ensure the functioning of the energy market and the security of energy supply in the Union. Yet even before the Lisbon Treaty, the still valid Third Gas Directive of July 2009, regulating the internal market in natural gas, ${ }^{14}$ also frequently mentions solidarity as a means to safeguard the internal market in natural gas (for example, in Article 6) as well as the importance of the internal market itself and the security of energy supply. It is therefore evident that these three principles - solidarity, a functioning internal energy market, and security of supply - constitute the paramount objectives of EU energy law. Nevertheless, in the light of Article 194(2) TFEU, which ensures that the measures taken under Article 194 TFEU will not affect the Member States' rights to choose energy resources and suppliers, solidarity in the context of energy law has been

14 Directive 2009/73/EC of the European Parliament and of the Council of 13 July 2009 concerning common rules for the internal market in natural gas and repealing Directive 2003/55/EC, OJ L 211/94, 14 August 2009. For an overview of the Third Gas Directive, see eg, Nicole Herweg, European Union Policy-Making: The Regulatory Shift in Natural Gas Market Policy (Palgrave Macmillan, Cham, 2017) 187-228; Katja Yafimava, "Transit: The EU Energy Acquis and the Energy Charter Treaty", in Kim Talus (ed), Research Handbook on International Energy Law (Edward Elgar, Cheltenham, 2014) 607-611. 
construed as "vague"15 and a mere "political"16 or "interpretative, rather than legally binding commitment". ${ }^{17}$ Others, conversely, argue that this approach is inaccurate, ${ }^{18}$ and even postulate that solidarity is a real and viable "constitutional principle"19 of Union law.

In this debate, I side with the second approach for two reasons. First, since the Lisbon Treaty abounds with explicit references to solidarity (most obviously in Article 222 TFEU, the 'solidarity clause'), ${ }^{20}$ it must have a certain meaning and import in EU law. Indeed, solidarity primarily governs the horizontal relationship between the Member States and represents the general political maxim that they are to support each other in any form. ${ }^{21}$ Solidarity is the general constitutional basis for the more specified legally binding principle of sincere cooperation in Article 4(3) $\mathrm{TEU},{ }^{22}$ and thus, the first is the logical match to the latter, which contributes the legally binding and enforceable rules integrating the Member States within the Union ${ }^{23}$ and further developing the internal market among them. And second, it stands to reason to construe solidarity as a duty of sincere cooperation especially in terms of security of energy supply. ${ }^{24}$ The reason for this is that the reference to the solidarity principle in Article 194 TFEU was included in response to requests made by the Polish government pertaining primarily to concerns over the security of gas supply from Russia,

15 Tomas Maltby, “European Union Energy Policy Integration: A Case of European Commission Policy Entrepreneurship and Increasing Supranationalism", 55 Energy Policy (2013),

435-444, at 440.

16 Marcus Klamert, The Principle of Loyalty in EU Law (oup, Oxford, 2014) 35.

17 Theodore Konstadinides, “Civil Protection in Europe and the Lisbon 'Solidarity Clause': A Genuine Legal Concept or a Paper Exercise' Uppsala Faculty of Law Working Paper (2011), 4-21.

18 See in particular Umut Turksen, EU Energy Relations with Russia: Solidarity and the Rule of Law (Routledge, London, 2018) 20.

19 Malcolm Ross and Yuri Borgmann-Prebil, Promoting Solidarity in the European Union (OUP, Oxford, 2010) 4.

$20 \quad$ Klamert, op.cit. note $15,36$.

21 Ibid., 40.

22 Case 6 \& 11/69 Commission v France [1969] ECR 523, para 16.

23 Klamert, op.cit. note $15,40$.

24 See, eg, Eglè Dagilytè, "Solidarity: A General Principle of EU Law? Two on the Solidarity Theme", in Andrea Biondi, Eglè Dagilytè, and Esin Küçük (eds), Solidarity in EU Law: Legal Principle in the Making (Edward Elgar. Cheltenham, 2018) 68; Christian Calliess, "Article 194 AEUV", in Christian Calliess and Matthias Ruffert (eds), EUV/AEUV: Kommentar $\left(4^{\text {th }}\right.$ edn; C.H. Beck, Munich, 2011) para 6. 
as illustrated in the gas disputes between Russia and Ukraine. ${ }^{25}$ Moreover, the principle of solidarity now also features abundantly in the 2017 Regulation on the Security of Gas Supply, ${ }^{26}$ which further underlines its significance in EU energy law. Article 13(1) of this Regulation expressly mentions that Member States may, in the case of a crisis, request solidarity from other Member States in the form of additional gas supply. Despite continuing discretion on the part of the Member States in implementing this provision, ${ }^{27}$ it is nonetheless evident that solidarity in EU energy law constitutes a clear legal obligation and cannot be simply disregarded as a vague political guideline.

\subsection{Solidarity in the Third Gas Directive: Unbundling and Third-Party Access}

As already mentioned above, solidarity in energy law can also be found in secondary EU law, most importantly in the Third Gas Directive, which slightly predates the entry into force of the Lisbon Treaty, but which is still in force. The general objective of this directive is to consolidate the Union's internal energy market by, inter alia, achieving competitive prices and contributing to security of supply in natural gas. To that end, the directive sets out various obligations, but for the purposes of this contribution I focus only on the following two central aspects: (i) the unbundling requirement and (ii) third-party access; these, in my view, best reflect the obligation to solidarity in energy law among the EU Member States.

\subsubsection{The 'Unbundling' Requirement}

'Unbundling' is a measure for dealing with gas transmission networks as natural monopolies, ${ }^{28}$ in which the transmission of energy is not typically carried

25 Johann-Christian Pielow and Britta Janina Lewendel, “Beyond 'Lisbon': EU Competences in the Field of Energy Policy", in Bram Delvaux, Michael Hunt, and Kim Talus (eds), EU Energy Law and Policy Issues (Intersentia, Cambridge, 2011), 300.

26 Regulation (EU) 2017/1938 of the European Parliament and of the Council of 25 October 2017 concerning measures to safeguard the security of gas supply and repealing Regulation (EU) No 994/2010, OJ L 280/1, 28 October 2017.

27 Fleming, op.cit. note 4 , 109-110.

28 See, eg, Richard A Posner, "Natural Monopoly and Its Regulation", 21(1) Stanford Law Review (1969), 548-643; Christopher Decker, Modern Economic Regulation: An Introduction to Theory and Practice (CuP, Cambridge, 2014) 227 and 283; Sergey Kirsanov, Evgeny Safonov, and Sandra Ramirez, "Natural Monopoly in Russia: State Regulation Problems", 5(1) Baltic Journal of Real Estate Economics and Construction Management (2017), 137-145, at 140 . 
out on a competitive basis, but by a single natural monopolist. ${ }^{29}$ Hence, to separate the competitive from the non-competitive segment in order to prevent misuse through control of the latter, ${ }^{30}$ energy transmission activities on the one hand are separated - or unbundled - from energy production or generation and supply activities on the other. ${ }^{31}$ The Third Gas Directive provides for three types of unbundling, varying in degree and intrusiveness, ${ }^{32}$ but they all pursue the same goal, namely safeguarding the neutrality of system operators in allocating gas transmission capacities to different network users. ${ }^{33}$ Accordingly, unbundling needs to be regarded as an invaluable instrument for promoting solidarity by improving competition and thereby the EU's internal energy market as well as the security of gas supply. This interpretation also conforms to the Commission's view that the now abandoned South Stream project was in breach of EU competition law because of its failure to provide for any unbundling. ${ }^{34}$ Currently, it seems that Gazprom intends to continue as the sole owner of Nord Stream 2 as well as a producer and supplier of gas, ${ }^{35}$ which would be in violation of the directive's unbundling requirement.

\subsubsection{The 'Third-Party Access' Requirement}

The 'third-party access' requirement is also an instrument for overcoming monopolist situations in gas transmission. In this case, however, it is not a natural monopoly that prevents fair competition, but a monopoly in infrastructure. As

29 Tilman Michael Dralle, Ownership Unbundling and Related Measures in the EU Energy Sector: Foundations, the Impact of WTO Law, and Investment Protection (Springer, Cham, 2017) 1.

$30 \quad$ Talus, op.cit. note 6, 79 .

31 Dralle, op.cit. note 28 , 2 .

32 See Art 9 of the Directive for 'ownership unbundling'; Arts 13-14 for the 'independent system operator' model of unbundling; and Arts 17-23 for 'independent transmission operator' unbundling. For an excellent overview of these models, see Dralle, op.cit. note 8 , 26-34, and Yafimava, op.cit. note $13,607-608$.

33 European Commission, "Request pursuant to the Framework Agreement - Nord Stream 2", 12 September 2017, 2.

34 Commission Decision of 24 May 2018 relating to a proceeding under Article 102 of the Treaty of the Functioning of the European Union (TFEU) and Article 54 of the EEA Agreement; Case AT.39816 - Upstream Gas Supplies in Central and Eastern Europe. See also Mikael Wigell and Antto Vihma, "Geopolitics versus Geoeconomics: The Case of Russia's Geostrategy and Its Effects on the EU”, 92(3) International Affairs (2016), 605-627, at 618; Rafael Kandiyoti, Powering Europe: Russia, Ukraine, and the Energy Squeeze (Palgrave Macmillan, New York, 2015) 69-73.

35 Alan Riley, "Nord Stream 2: A Legal and Policy Analysis", 151 CEPS Special Report (2016), $1-27$, at 10 . 
it is economically nonsensical to construct more than one physical gas pipeline network for any given project, it follows that all producers and suppliers in a market are then dependent on that one network. Gas networks therefore have an inbuilt monopoly character that must be regulated; first and foremost through third-party access, which obligates pipeline operators to grant market competitors access to the gas pipeline in question in a non-discriminatory way in order to allow for fair competition and security of supply. ${ }^{36}$ The Third Gas Directive in its Article 32 provides such a legal right for third parties to access and use the grid of a gas transmission system owner and thereby guarantees the goal of the internal gas market wherein gas can be transported and traded freely across Member State borders. Thus, third-party access, in the same way as unbundling, must be seen as an instrument for fostering solidarity among the Member States in terms of energy competition and security. In the context of Nord Stream 2, it needs to be noted at the outset that this requirement conflicts with Russian legislation providing Gazprom with an export monopoly on gas. ${ }^{37}$ The Russian Federation could certainly lift this export monopoly legislation in order to comply fully with EU law. However, that seems unlikely at the moment. 38

\subsubsection{Certifications and Possible Exemptions}

In this light, it is crucial also to examine Article 11 of the Third Gas Directive, which stipulates that certification for compliance with the unbundling and third-party access requirements is to be refused if a transmission system owner involved in the process is controlled by persons from a third country that does not comply with these two requirements or if granting certification will put the security of energy supply to the Union at risk. In academic circles and beyond, Article 11 has already colloquially been dubbed the 'Gazprom clause'. The reason for this is that, whilst the provision certainly applies to all third countries, it has clearly been drafted to apply primarily to the Russian natural gas monopoly Gazprom. ${ }^{39}$ As a consequence, it constitutes a considerable barrier for Gazprom to own and operate transmission networks within the EU, seeing that it does not comply with the requirements of the Third Gas Directive. ${ }^{40}$

\footnotetext{
36 Talus, op.cit. note 6, 19 .

37 Federal Act of the Russian Federation No.117 FZ of 18 July 2006.

38 Riley, op.cit. note \%, $^{11}$.

39 Moritz Wüstenberg and Kim Talus, "wTo Law Perspectives on EU-Russia Energy Trade: Worlds Apart or Minor Differences", 11(4) Journal of World Energy Law and Business (2018), $360-371$, at 362 .

Yafimava, op.cit. note 608 n 42.
} 
But even beyond that, in bypassing the EU Member States of Central and Eastern Europe, Nord Stream 2 might pose a supply risk to these States. One could of course argue that Member States like Germany, having then full access to gas supply, could then be requested to show solidarity and guarantee supply security via the German pipeline system into these affected States. Yet even if German goodwill can be guaranteed, these States will nonetheless face significant extra costs as a result of the transit fees necessary to bring gas via Nord Stream 2 and the German pipeline network. Given these risks and the clear non-compliance with the requirements of the Third Gas Directive, it is difficult to see how Nord Stream 2 can be certified for the purposes of Article $11 .{ }^{41}$

One solution to circumvent the requirements of EU energy law is to seek an exemption for Nord Stream 2 under Article 36 of the Directive. This provision states that in order to encourage investment in new infrastructure, an exemption for a defined period of time from the application of the full rigor of the Directive is possible, namely for interconnectors, if this new infrastructure enhances competition in gas supply and security of supply (Article 36(1)(a)). Accordingly, for that period the requirements of unbundling and third-party access would not apply to Nord Stream 2. Prima facie, it seems that the exemption in Article 36 would not apply, as Article 2(17) of the Directive defines an 'interconnector' as a transmission line crossing or spanning a border between Member States for the sole purpose of connecting their national transmission systems. It is evident that Nord Stream 2 connects pipeline networks between EU Member States and a non-EU Member State - that is, Russia - which would prevent application of Article 36 . However, Recital 35 of the Directive clearly states that, for security of supply reasons, temporary derogations from the strict requirements of the Directive should also apply to new pipelines within the Union transporting gas from third countries into the Union. Disregarding the editorial mistake in Article 2(17) read in conjunction with Article $36(1)$ would then suggest that an exemption under Article 36 is indeed possible. Nonetheless, the actual application of such an exemption is extremely unlikely for three reasons. First, Gazprom has not filed an exemption request for Nord Stream 1 or South Stream, so it is improbable that they would do so in the case of Nord Stream 2. Second, Gazprom would have great difficulty in complying with the strict conditions for an exemption under Article 36(1), as Nord Stream 2 would enhance neither competition in gas supply nor security of supply. Third and last, if Gazprom filed for an exemption, it would thereby have to subject itself to intense regulatory scrutiny by the Commission, which

41 Riley, op.cit. note $34^{12-13}$. 
might not be a very appealing prospect. ${ }^{42}$ Another interesting corollary here would be that filing for an exemption would also show that Gazprom accepts the applicability of EU law to Nord Stream 2 in the first place, which is a step it may attempt to avoid anyway because of the Directive's strict requirements.

\subsection{Legal Opinion of the Commission and Council: Non-Applicability of the Third Gas Directive to Nord Stream 2}

After this overview of solidarity in EU energy law and its main elements, I now return to the main question at hand, namely whether EU law in general and the Third Gas Directive in particular are applicable to Nord Stream 2. While it is undisputed that the onshore extension of this pipeline system will be subject to EU law, it is currently unclear whether these same rules will also extend to its offshore infrastructure. The decisive issue here is the nature and legal definition of the pipeline. The Nord Stream 2 consortium regards the system as an import pipeline whose sole function is to transport gas to the border of the internal energy market. ${ }^{43}$ As such (and as already mentioned above), Nord Stream 2 would not fall under the rubric of transmission infrastructure or interconnector within the meaning of Article 2(17) of the Third Gas Directive and hence not the scope of this directive. In fact, it would be comparable to existing pipelines carrying non-EU gas to Europe ${ }^{44}$ such as Green Stream (between Libya and Italy), the Maghreb-Europe pipeline (Algeria-MoroccoSpain), Medgaz (Algeria-Spain), the Transmed Pipeline (Algeria-Tunisia-Italy), or Galsi (Algeria-Italy). None of these import pipelines are subject to EU law and are therefore required to fulfil unbundling or third-party access requirements. ${ }^{45}$ However, the main difference between these pipelines and Nord Stream 2 is that they are not - as Gazprom is - the sole owners as well as producers and suppliers of gas.

The problem remains that this legal uncertainty leaves ample room for a politically motivated interpretation of the law. Interestingly, in 2017, both the European Commission and the Council of the EU concluded - despite some substantive differences - that the offshore elements of Nord Stream 2 would not be subject to the Third Gas Directive. The Commission states that neither

$42 \quad$ Ibid., 13-16.

43 Andreas Goldthau, "Assessing Nord Stream 2: Regulation, Geopolitics \& Energy Security in the EU, Central Eastern Europe \& the UK", European Centre for Energy and Resource Security (EUCERS) and King's Russia Institute, 2016, 22.

Simon Pirani and Katja Yafimava, "Russian Gas Transit across Ukraine Post-2019: Pipeline Scenarios, Gas Flow Consequences, and Regulatory Constraints", Oxford Institute for Energy Studies, OIEs Paper: NG 105, February 2016, 
the EU nor its Member States could claim jurisdiction over the part of an offshore pipeline outside their territory, and likewise, no third country could impose application of its national jurisdiction on such offshore pipelines outside of its territory. This situation results either in a legal void or in the application of two different and perhaps contradictory legal regimes to one and the same stretch of pipeline, which is not acceptable either. ${ }^{46}$ The Council agrees that no such jurisdiction could be claimed by either the Union and its Member States or a third country, and that consequently EU law cannot be applied, but this would not necessarily lead to a legal void, as the offshore parts of the pipeline would in any event be subject to the relevant rules of international law, in particular the law of the sea. ${ }^{47}$ In a second legal opinion, the Commission then argues that EU law in general would be applicable within the territorial waters and the exclusive economic zones of a Member State as well as - insofar as offshore pipelines are concerned - between the landing point in a Member State and the first connection to the offshore network. However, the general territorial jurisdiction of EU law does not necessarily coincide with the specific scope of the respective provisions of secondary EU law. The reason for this is that the regulatory framework of the Third Gas Directive, wherein third-party access and unbundling should contribute to the opening of the EU gas market, does not expressly provide for the application of these rules to an offshore import pipeline connecting a Member State with a third country. This absence of such specific rules on pipelines from third countries such as Nord Stream 2 indicates that the legislator did not intend these rules to apply in those cases, in particular as application would make them unilaterally binding on third countries ${ }^{48}$ and hence have an extraterritorial effect, which would be unjustifiable under general international law. ${ }^{49}$

46 European Commission, "Recommendation for a Council Decision authorising the opening of negotiations on an agreement between the European Union and the Russian Federation on the operation of the Nord Stream 2 pipeline", $\operatorname{com}(2017) 320$ final, Doc. 10249/17, 12 June 2017, 4.

47 Council of the European Union, "Opinion of the Legal Service: Recommendation for a Council Decision authorising the opening of negotiations on an agreement between the European Union and the Russian Federation on the operation of the Nord Stream 2 pipeline - Allocation of competences and related legal issues", Doc. 12590/17, 27 September 2017,5 .

48 European Commission, "Request pursuant to the Framework Agreement - Nord Stream 2", Ares(2017)s4728131, 12 September 2017, 2-3.

49 See, in general, Kim Talus and Moritz Wüstenberg, "Risk of Expanding the Geographical Scope of EU Energy Law", 26(5) European Energy and Environmental Law Review (2017), 138-147. 
These arguments, coming from the Commission and the Council, show that - at least prima facie - EU law is not applicable to Nord Stream 2, and they also demonstrate a certain unwillingness on the part of these two bodies to construe Union law as applicable. This situation will endure until the Commission's plan to extend these common EU gas rules to import pipelines is effectively implemented. ${ }^{50}$ Yet until then, this status quo raises the question whether Nord Stream 2 might interfere with the EU's objectives of solidarity, the functioning of the energy market, and security of energy supply, if the rules of unbundling and third-party access do not apply to this pipeline system.

3

The Applicability of International Law

Assuming that EU law in general and the Third Gas Directive in particular do not apply to the offshore parts of the Nord Stream 2 pipeline system, it stands to reason, as the Council stated in its legal opinion, ${ }^{51}$ that this pipeline system will be governed by international law - although it remains to be seen by which specific international legal regime. The most viable candidates are the Energy Charter Treaty, the respective rules of the World Trade Organization (WTO), and the law of the sea. However, one substantial problem remains, and that is whether - given the inapplicability of EU law - its requirements of unbundling and third-party access could be guaranteed, albeit only indirectly, by international law. In the following sections I will therefore investigate whether this is the case and if one of these international legal regimes could safeguard these requirements in the same way and according to the same standards as EU law, starting with the most specific, the Energy Charter Treaty, continuing with the subsidiary rules of the WTO, and concluding with the general rules of the law of the sea.

\subsection{The Energy Charter Treaty}

The Energy Charter Treaty (ECT) entered into force in 1998 and is a unique multilateral treaty, as it establishes within the energy sector detailed rights and obligations with respect to a broad range of investment, trade, and improvement of energy efficiency. As described in its Article 4, the objective is to "establish a legal framework in order to promote long-term cooperation in

$5^{\circ} \quad$ For further details, see the contribution by Nina Zafoschnig ...in this issue.

$5^{1}$ See Council of the European Union, op.cit. note 46, 5 . 
the energy field, based on complementarities and mutual benefits [...]."52 This spirit of cooperating in the energy sector is perhaps best expressed by another purpose of this treaty, which is the most relevant for the purposes of the present discussion, namely, common rules for the transit of energy, including a transit non-interference clause and a specific transit dispute conciliation procedure, thereby putting into place an internationally supervised transit regime for energy. ${ }^{53}$ This principle of freedom of transit is enshrined in Article 7 ECT, which, in paragraph 1, obliges the parties to "take the necessary measures to facilitate the transit of energy materials and products consistent with the principle of freedom of transit." This provision is based on Article V of the General Agreement on Tariffs and Trade (GATT), ${ }^{54}$ although it has been argued that it is narrower in scope than this source provision. ${ }^{55}$ Freedom of transit under the ECT operates on a non-discriminatory basis in terms of access to pipeline networks (Article $7(1)$ ) and rights to construct new transit capacities (Article $7(2))$. Article $7(7)$ further ensures no interruption or reduction in the flow of energy materials and products as well as, in the case of a dispute, a conciliation procedure.

Given the importance of secure energy transit across multiple national boundaries, negotiations on a Transit Protocol started in 2000, aimed at clarifying, complementing, and strengthening Article 7 ECT, and accordingly it would have been only open to States that had already ratified the ECT first. ${ }^{56}$ Multilateral negotiations were completed in 2002, while some issues remained to be resolved between the EU and Russia on the basis of bilateral negotiations. However, these negotiations were suspended and finally frozen after the

$5^{2}$ For a comprehensive overview, see, eg, Craig S Bamberger, "An Overview of the Energy Charter Treaty", in Thomas W Wälde (ed), The Energy Charter Treaty: An East-West Gateway for Investment and Trade (Kluwer, The Hague, 1996) 1-34; Kaj Hobér, "The Energy Charter Treaty: An Overview", 8(3) Journal of World Investment \& Trade (2007), 323-355; and Thomas Roe, Matthew Happold, and James Dingemans QC, Settlement of InvestorState Disputes under the Energy Charter Treaty (CuP, Cambridge, 2011).

53 Yafimava, op.cit. note 13 611 .

54 See Turksen, op.cit. note 17, 50, and Andrey Konoplyanik, "Russia-EU Summit: WTO, the Energy Charter Treaty and the Issue of Energy Transit", (2) International Energy Law and Taxation Review [2005], 30-35.

55 See, eg, Yafimava, op.cit. note 612; Martha M. Roggenkamp, "Transit of Network-Bound Energy: The European Experience”, in Thomas W Wälde (ed), The Energy Charter Treaty: An East-West Gateway for Investment and Trade (Kluwer, The Hague, 1996) 512.

56 See Andrey Konoplyanik, "Russia-EU, G-8, ECT and Transit Protocol", 4(3) Russian/cIs Energy \& Mining Law Journal (2006), 9-12. 
Russian government decided not to become a contracting party to the ECT and terminated its provisional application in 2009. ${ }^{57}$

This is exactly the point where a possible application of the ECT to Nord Stream 2, in order to guarantee the EU requirements of unbundling and thirdparty access, becomes extremely problematic for various reasons. To begin with, both the ECT itself ${ }^{58}$ and the (draft) Transit Protocol ${ }^{59}$ emphasize that contracting parties are not obliged to introduce mandatory third-party access, nor do they mention the unbundling requirement at all. ${ }^{60}$ Accordingly, in substance, the ECT would not and could not serve the purpose of guaranteeing these requirements in the absence of EU law. Second, even though all the EU Member States as well as the EU itself are among the contracting parties to the ECT, the Russian Federation is not. Russia signed the treaty, but never ratified it, and - as already mentioned above - only applied it provisionally under its Article $45^{61}$ until 2009, when it terminated the provisional application ${ }^{62}$ for several reasons. ${ }^{63}$ This means that even if the ECT contained any requirements on unbundling and third-party access in the context of Nord Stream 2, Russia would - as a mere signatory - not be legally bound by it. Russia's only obligation as a signatory is to refrain from any acts which would defeat the object and the purpose of the treaty under Article 18 of the Vienna Convention on the Law of Treaties (VCLT), but again, seeing that both the ECT and the draft Transit Protocol do not oblige the contracting parties (or signatories, for that matter) to introduce mandatory third-party access and unbundling, Russia is in no position to defeat such a non-existent object and purpose in any case. Third and last, one could argue that according to Article 45(3)(b) ECT, Russia remains

57 Yafimava, op.cit. note $13,612-613$; Turksen, op.cit. note $17,5^{0-51}$.

$5^{8}$ Understanding $1(\mathrm{~b})(\mathrm{i})$ ЕСТ: "The provisions of the Treaty do not oblige any Contracting Party to introduce mandatory third party access $[\ldots] . "$

59 Preamble, third recital of the Transit Protocol: "Recalling that pursuant to Understanding $1(b)$ of the Treaty [i.e. the ECT], the provisions of the Treaty and this Protocol do not oblige any Contracting Party to introduce mandatory third party access [...]."

6o Talus, op.cit. note 6, 243; Andrey Konoplyanik, "The Role of the ECT in EU-Russia Energy Relations", in Rafael Leal-Arcas and Jan Wouters (eds), Research Handbook on EU Energy Law and Policy (Edward Elgar, Cheltenham, 2017) 133.

61 See William Spiegelberger, "The Enforcement of Foreign Arbitral Awards in Russia: An Analysis of the Relevant Treaties, Laws, and Cases", 16(2) American Review of International Arbitration (2005), 261-313, at $271 \mathrm{fn}$ 48; Peter C. Laidlaw, "Provisional Application of the Energy Charter as Seen in the Yukos Dispute", 52(2) Santa Clara Law Review (2012), $655^{-684}$, at $665^{-666 .}$

62 Which is possible under Article 45(3) of the ECT. See also Turksen, op.cit. note 17, 50.

63 See Turksen, op.cit. note $17,54-55$. 
bound by the ECT's dispute settlement clauses, most importantly Article 26 on investor-State disputes, for another twenty years (thus expiring only in 2029), which was also proven by the Yukos ${ }^{64}$ and Hulley ${ }^{65}$ arbitral awards of 2014 (that is, after termination of the ECT's provisional application), in which the Permanent Court of Arbitration relied on the ECT as the relevant applicable law.

This means, in conclusion, that the ECT cannot guarantee the same requirements as EU law in terms of unbundling and third-party access and is not even applicable to Nord Stream 2.

\subsection{Relevant WTo Rules}

Seeing that the leges speciales of the ECT regime do not apply to Nord Stream 2 , it is possible that the relevant rules of the more general WTO system might govern the unbundling of and third-party access to this pipeline. Both the EU itself as well as its Member States in their own right ${ }^{66}$ and the Russian Federation $^{67}$ are members of the wTO, which means that the relevant rules would be binding on all parties involved. However, the crucial question remains whether the WTO agreements cover energy goods and services as a distinctive sector, ${ }^{68}$ and subsequently, whether the most suitable candidates, namely (i) the GATT and (ii) the General Agreement on Trade in Services (GATS), can safeguard third-party access and unbundling in the context of Nord Stream 2.

\subsubsection{Applicability of the GATT}

The original GATT did not contain any specific rules related to energy trading, which might historically be explained by the underdeveloped state of crossborder energy trading particularly in grid-linked sales of gas, at the time of the GATT negotiations. ${ }^{69}$ Today, it is nevertheless undisputed that the fundamental

64 Yukos Universal Limited(Isle of Man) v the Russian Federation, PCA Case No. AA 227, 18 July 2014.

65 Hulley Enterprises Limited (Cyprus) v the Russian Federation, PCA Case No. AA 226, 18 July 2014.

66 The EU (or more correctly: its legal predecessor the European Communities) has been a WTO member since 1 January 1995. For a critical discussion of this parallel membership and the weighing of votes, see, eg, Frank Hoffmeister, "Institutional Aspects of Global Trade Governance from an EU Perspective" in Bart Van Vooren, Steven Blockmans, and Jan Wouters (eds), The EU's Role in Global Governance: The Legal Dimension (oup, Oxford, 2013) 147-148.

67 The Russian Federation acceded to the wTо on 22 August 2012.

68 Turksen, op.cit. note 17,59 .

69 Yulia Selivanova, "The wTo Agreements and Energy" in Kim Talus (ed), Research Handbook on International Energy Law (Edward Elgar, Cheltenham, 2014) 275. 
principles of the WTO, first and foremost the principle of the most-favored nation treatment enshrined in Article I.1 GATT, equally apply to the energy sector, thus covering trade in gas. ${ }^{70}$ Trade in gas squarely falls within the area of 'trade in goods' regulated by the wTO Multilateral Agreements on Trade in Goods, listed in Annex 1A to the wTo Agreement, including the GATт. ${ }^{71}$ This can be easily argued as natural gas has a physical composition, can be bought and sold in the market like any other merchandise, and is transportable via pipelines, ${ }^{72}$ and therefore perfectly fits the definition of a 'good' as a "physical [object] for which a demand exists, over which membership rights can be established and whose ownership can be transferred from one institutional unit to another by engaging in transactions on markets". ${ }^{73}$ Furthermore, in the very first dispute decided by the Appellate Body, the US - Gasoline case ${ }^{74}$ no party contested the regulation of trade in energy and energy products under the GATT and other applicable Agreements on Trade in Goods in Annex 1A to the WTO Agreement. ${ }^{75}$ As a consequence, the GATT certainly applies to measures affecting trade in gas as a good, notably its Article V.1 which defines the notion of 'traffic in transit' as 'goods', and hence applies to the traffic of gas in transit. ${ }^{76}$ Furthermore, the first sentence of Article $1(2)$ integrates the principle of freedom of transit into the GATT by providing that " $[\mathrm{t}]$ here shall be freedom of transit through the territory of each contracting party, via the routes most convenient for international transit, for traffic in transit to or from the territory of other contracting parties."

The application of Article V.2 GATT and freedom of transit, in turn, raises another set of questions, namely: seeing that it does not explicitly mention third-party access and unbundling, does it nonetheless somehow allow for them in the context of Nord Stream 2? Concerning third-party access, the scholarly literature is characterized by conflicting interpretations. Some

\footnotetext{
$70 \quad$ Ibid., 280-289; Talus and Wüstenberg, op.cit. note 48, 144-147.

71 Vitaliy Pogoretskyy, Freedom of Transit and Access to Gas Pipeline Networks under WTO Law (CUP, Cambridge, 2017) 120.

72 See ibid., 120-121. See also Beatriz H. Melgar, The Transit of Goods in Public International Law (Brill, Leiden, 2015) 7-10; and Lothar Ehring and Yulia Selivanova, "Energy Transit" in Yulia Selivanova (ed), Regulation of Energy in International Trade Law: WTO, NAFTA, and Energy Charter (Kluwer, Aalphen aan den Rijn, 2011) 57-58.

Organisation for Economic Co-operation and Development (OECD), "Glossary of Statistical Terms", https://stats.oecd.org/glossary/detail.asp?ID=1129 (accessed 3 January 2019). United States - Standards for Reformulated and Conventional Gasoline, Panel and Appellate Body Report adopted on 20 May1996, WT/DS2/9.

75 Pogoretskyy, op.cit. note 79, 122.

76 Ibid.
} 
scholars regard a right to third-party access as flowing directly from the freedom of transit as $\operatorname{such}^{77}$ or construe it as a compulsory right which can be enforced even against "private companies, whose conduct is not attributable to the State"; ${ }^{78}$ whilst others, conversely, deny the existence of such a right under the GATT altogether. ${ }^{79}$ As a middle ground between these two extreme positions, Vitaliy Pogoretskyy suggests that the obligation to provide freedom of transit under the first sentence of Article V.2 GATT may solely include ancillary rights related to this freedom. There is certainly no positive obligation imposed on wто members to construct pipeline facilities in their respective territories or to enforce a compulsory third-party access right against a private pipeline operator. However, since it is generally recognized that freedom of gas transit cannot be effected without access to pipeline infrastructures, an outright refusal of such access would appear to be inconsistent with Article V.2 GATT. ${ }^{80}$ This means that if we accept the principle of freedom of transit as a principle of general international law, ${ }^{81}$ then it can only be seen as an 'imperfect right', because its implementation effectively requires conclusion of an agreement between the parties involved in order to guarantee third-party access to the

77 See, eg, Ehring and Selivanova, op.cit. note 73, 70-71;

78 Danae Azaria, Treaties on Transit of Energy via Pipelines and Countermeasures (oup, Oxford, 2015) 63-67.

79 See, eg, Mireille Cossy, "Energy Trade and wTo Rules: Reflexions on Sovereignty over Natural Resources, Export Restrictions, and Freedom of Transit” in Christoph Herrmann and Jörg Philipp Terhechte (eds), European Yearbook of International Economic Law (Springer, Heidelberg, 2012) 298-299; Andrei A Konoplyanik, "Russia-EU Summit: wTo, the Energy Charter Treaty and the Issue of Energy Transit", 2(1) International Energy Law and Taxation Review (2005), 30-35, at 32; Vladimir Rakhmanin, "Transportation and Transit of Energy and Multilateral Trade Rules: wTо and Energy Charter" in Joost Pauwelyn (ed), Global Challenges at the Intersection of Trade, Energy, and the Environment (The Graduate Institute, Centre for Trade and Economic Integration, Geneva, 2010) 124.

8o Pogoretskyy, op.cit. note $70,146-147$.

81 See, eg, Hugo Grotius, The Rights of War and Peace; vol 2 (Richard Tuck and Jean Barbeyrac (eds); Liberty Fund, Indianapolis, 2005) chapter 2, and Samuel von Pufendorf, De jure naturae et gentium libri octo; vol 2 (James Brown Scott (ed); Clarendon Press, Oxford, 1934) 354, for natural law arguments; Elihu Lauterpacht, "Freedom of Transit in International Law", 44 Transactions of the Grotius Society (1958), 313-356, at 319-320, 332-333, 335-338, and 346, for necessity and bona fides arguments; Lucius Caflisch, "Land-locked States and their Access to and from the Sea", 49 British Yearbook of International Law (1979), 71-100, at 78 , and Eyal Benvenisti, "Sovereigns as Trustees of Humanity: On the Accountability of States to Foreign Stakeholders", 107(2) American Journal of International Law (2013), $295^{-3} 33$, at 320,322 , and 327 , for arguments based on innocent passage and international cooperation. 
pipeline in question. ${ }^{82}$ The result would be an obligation to negotiate such an implementation agreement in good faith and a prohibition of abuse of rights, and compulsory third-party access rights should thus not be implied lightly in Article V.2 GATT. ${ }^{83}$ Yet again, in the context of Nord Stream 2, another problem rears its ugly head, namely the fact that there will most probably be no implementation agreement between the EU and Russia on this pipeline project, which would then defeat the actual implementation of these ancillary rights in practice. This would mean, in conclusion, that Article V.2 GATT cannot guarantee third-party access rights to Nord Stream 2.

The unbundling requirement is not covered by Article V GATT either, as unbundling itself is directed against the anti-competitive practice of vertical integration (wherein the supply of gas is provided for by the owner of the pipeline, that is, here: Gazprom) and therefore not an obligation imposed upon wTO members in order to safeguard freedom of transit. In fact, unbundling policies address private conduct that impedes cross-border trade in energy goods and services, with discriminatory network access being the main issue here. Historically seen, however, it is governmental restraints which have represented the most significant limitations on world trade; and consequently, it becomes evident that where governmental trade barriers exist and competition is categorically ruled out, the issue of network access does not arise in the first place. Hence, in order for unbundling measures to become actually relevant and effective, it is necessary to guarantee that there are no governmentally imposed barriers to energy trade; only then can unbundling measures play a meaningful role and prevent private market actors from impeding market access. ${ }^{84}$

Within the framework of GATT, Article XVII on 'State Trading Enterprises' has a certain competition dimension and could therefore be relevant in the present discussion. Article XVII.1 GATT in particular obligates WTO members to ensure that State trading enterprises (that is, State enterprises and enterprises with exclusive or special privileges) act - when purchasing or selling either imports or exports - "in a manner consistent with the general principles of non-discriminatory treatment prescribed [in the GATT] for governmental measures affecting imports or exports by private traders." This effectively means that WTO members cannot, through such State trading enterprises,

\footnotetext{
82 Pogoretskyy, op.cit. note 79,64 and 147 .

83 Ibid., 235 and 241.

84 TilmanMichael Dralle, Ownership Unbunding and Related Measures in the EUEnergy Sector: Foundation, the Impact of WTO Law and Imestment Protection (Springer, Cham, 2018), $273^{-274}$.
} 
undertake or facilitate conduct that would be considered discriminatory under the GATT if such conduct were directly carried out by the State itself. ${ }^{85}$

The problem remains - as will be explained in the following paragraphs that Article XVII GATT has only a very limited ability to ensure that vertically integrated energy undertakings such as Nord Stream 2 are subject to unbundling measures. ${ }^{86}$ To begin with, it is true that entirely or predominantly State-owned or State-controlled companies are automatically covered by this provision, ${ }^{87}$ but the same does not apply to private entities, as it is then additionally necessary to demonstrate that "exclusive or special privileges" have been granted. ${ }^{88}$ It has been argued that such rights and privileges can be considered exclusive or special if they enable the enterprise to influence trade flows; ${ }^{89}$ and on that basis, the mere fact of having control over a transportation network would be sufficient to meet the definition of "exclusive or special privileges". 90 Tilmann Dralle, however, contends that this interpretation is incorrect, since this ability to "influence $[. .$.$] the level or direction of imports or exports" mentioned$ in the working definition of State trading enterprises in the Understanding on the Interpretation of Article XVII GATT 1994, was included for notification purposes only and is thus 'without prejudice' to the substantive obligations in Article XVII GATT. ${ }^{91}$ Furthermore, even under the 1994 Understanding, the ability to "influence [...] the level or direction of imports or exports" is merely a necessary - but not a sufficient - condition to qualify as a State trading enterprise, because the grant of exclusive or special privileges is still required. Consequently, a vertically integrated energy undertaking that has control over a transmission network cannot be considered a State trading enterprise simply because its network-related activities affect imports and exports of gas; for that

85 Canada-Measures Relating to Exports of Wheat and Treatment of Imported Grain, Report of the Appellate Body of 30 August 2004, WT/DS276/AB/R, para 85.

86 Dralle, op.cit. note 83289 .

87 Tania Voon, "Article XVII GATT" in Rüdiger Wolfrum, Peter-Tobias Stoll, and Holger P Hestermeyer (eds), WTO - Trade in Goods (Martinus Nijhoff, Leiden, 2011) para 4.

88 Dralle, op.cit. note 8 , 289 .

89 Yulia Selivanova, Energy Dual Pricing in the wTo: Analysis and Prospects in the Context of Russia's Accession to the World Trade Organization (Cameron May, London, 2008) 100.

90 Selivanova, op.cit. note 291-292; Yulia Selivanova, The wTo and Energy: WTo Rules and Agreements of Relevance to the Energy Sector (International Centre for Trade and Sustainable Development, Geneva, 2007) 19.

91 Dralle, op.cit. note 83, 289; Ernst-Ulrich Petersmann, “GATT Law on State Trading Enterprises: Critical Evaluation of Article XVII and Proposals for Reform" in Thomas Cottier and Petros C Mavroidis (eds), State Trading in the Twenty-First Century (University of Michigan Press, Ann Arbor, 1998) 80 and 92-93. 
definition to apply, some level of facilitating State action is needed in order for a natural monopoly situation to fall under Article XVII GATT. ${ }^{92}$

It should be highlighted that Gazprom was explicitly notified to be a State trading enterprise by Russia during its wTO membership negotiations. ${ }^{93}$ The company exercises control over the gas pipeline network and major processing plants, as well as negotiating and administering bilateral contracts for the supply of gas to Europe. Furthermore, it has had a legal monopoly on gas exports from Russia since June 2006. This suggests that all these activities correspond to the notion of "exclusive or special rights or privileges",94 as by doing so Gazprom can indeed influence exports by its selling activities. ${ }^{95}$ The Nord Stream 2 pipeline itself, however, is being built and run by Nord Stream 2 AG, a public limited company incorporated under Swiss law; but seeing that it is a wholly owned subsidiary of Gazprom, it is simply an extension of the latter as a State trading enterprise and should also be considered as such. This would mean that both Gazprom as well as its subsidiary Nord Stream 2 AG are covered by Article XVII GATT.

Yet that is not sufficient to guarantee the unbundling requirement under this provision. There are two factors limiting the effectiveness of Article XVII GATT regarding unbundling requirements in the context of Nord Stream 2: first, neither of the the substantive obligations in Article XVII.1(b) GATT providing, inter alia, that State trading enterprises are to make sales of exports solely in accordance with 'commercial considerations' and afford 'adequate opportunity' to compete for participation in sales - constitutes a self-standing obligation. ${ }^{96}$ This was also clarified by the Appellate Body in Canada - Wheat Exports and Grain Imports, wherein it stated that the main obligation on State trading enterprises is contained in Article XVII.1(a) GATT, obliging them to act in a manner consistent with the "general principles of non-discriminatory treatment" prescribed in the GATT. Subparagraph (b) hence merely clarifies

\footnotetext{
92 Dralle, op.cit. note ${ }_{3} 290$.

93 WTO, Report of the Working Party on the Accession of the Russian Federation to the World Trade Organization, WT/ACC/RUS/7o (17 November 2011) para 88. See also Peter Naray, Russia and the World Trade Organization (Palgrave Macmillan, London, 2001) 125.

94 Vitaliy Pogoretskyy, "Energy Dual Pricing in International Trade: Subsidies and AntiDumping Perspectives" in Yulia Selivanova (ed), Regulation of Energy in International Trade Law: WTO, NAFTA, and Energy Charter (Kluwer, Aalphen aan den Rjin, 2011) 195, fn 63. See also Lars Petter Lunden, Daniel Fjaertoft, Indra Overland, and Alesia Prachakova, "Gazprom vs. other Russian Gas Producers: The Evolution of the Russian Gas Sector", 61(10) Energy Policy (2013), 663-670.

95 See also Naray, op.cit. note 92,125 .

$96 \quad$ Dralle, op.cit. note $\&_{2} 291$.
} 
the scope of subparagraph (a). ${ }^{97}$ This means that, in practice, if Gazprom offers to sell gas at an unreasonable price, thereby effectively foreclosing access to the Nord Stream 2 transmission network, this opportunity to compete cannot be regarded as 'inadequate', nor does Gazprom fail to act 'commercially' in a broad sense, thus giving rise to a violation of Article XVII.1(b) GATT. ${ }^{98}$ In fact, the language of subparagraph (b) cannot be construed "as imposing comprehensive competition-law-type obligations on [State trading enterprises]"99 and has therefore to be interpreted rather narrowly, ${ }^{100}$ which would prevent its application as an unbundling requirement to Nord Stream 2. And second, the reference to the "general principles of non-discriminatory treatment" in Article XVII.1(a) GATT is to be understood to the effect that a State trading enterprise must act in a manner consistent with these general principles only in "its purchases or sales involving either imports or exports". When considering the ordinary meaning of this phrase, it becomes clear that there is no obligation on Gazprom to actually export energy products and that only if it decides to trade in foreign goods must it respect these general principles mentioned in Article XVII GATT. Hence, even if a vertically integrated energy company such as Gazprom qualifies as a State trading company within the meaning of this provision, it is not required to grant any particular form of access to the gas transmission networks it controls. ${ }^{101}$

In conclusion, any obstacles encountered by the cross-border trade in energy goods, such as vertical foreclosure of transmission networks like Nord Stream 2, fall out of the scope of the GATT, ${ }^{102}$ and do not require unbundling. ${ }^{103}$ Article XVII GATT can therefore not guarantee the unbundling requirements within the context of Nord Stream 2.

\subsubsection{Applicability of the GATS}

Some aspects of gas transportation required for transit may also be regulated by the GATs, which could therefore allow for third-party access to and unbundling of the Nord Stream 2 system (even though it should be mentioned that the GATS - like the GATT - remains equally silent on these requirements). Its

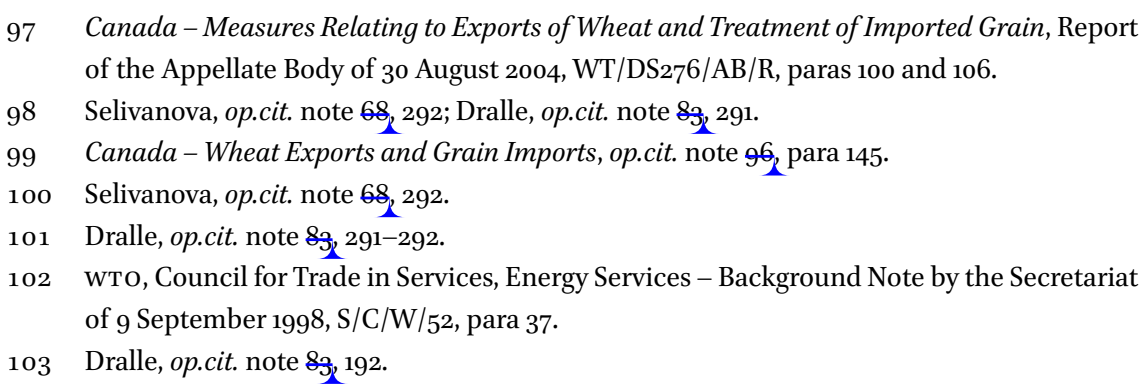


scope is broadly defined in Article I.1 by establishing that it "applies to measures by Members affecting trade in services", ${ }^{104}$ thus also - in principle covering trade in energy. However, as will be seen below, the GATs suffers from significant limitations as far as the third-party access and unbundling requirements are concerned.

To begin with, adoption of the GATs has not automatically led to legal and comprehensive liberalization of the energy services market. The reason for this is mainly the peculiar structure of the GATS, under which key obligations such as market access only apply if and to the extent that the respective WTO member has undertaken specific commitments in its specific schedule of commitments. Concerning the energy sector, WTO members have principally been highly reluctant to make such commitments. ${ }^{105}$ Russia only undertook relatively modest commitments under the GATS with respect to energy services and did not include trade in gas services in them, ${ }^{106}$ which is also reflected in the ambiguous language it used, stating that it "would apply all its [...] measures governing transit of goods (including energy) in conformity with GATT and WTO provisions", 107 thus explicitly omitting the GATS.

Furthermore, it seems that production and generation of electricity and gas does not even constitute a service within the meaning of the GATs. ${ }^{108}$ In other words, measures relating to production and generation of energy are not covered by the GATS and WTO members cannot undertake specific market access and national treatment commitments in this part of the energy sector. ${ }^{109}$ As a consequence, in the absence of relevant specific commitments and autonomous liberalization, all segments of the gas sector of Russia as a WTO member may be dominated by a State monopoly, and thus there would be no scope for international competition. ${ }^{110}$ All of these aspects undoubtedly apply to

\footnotetext{
104 Emphasis added.

105 Dralle, op.cit. note 8 93-101 and 274.

106 See Vitaliy Pogoretskyy and Sergii Melnyk, "Russian Energy and the wTo: Overview of the Accession Negotiations of the Russian Federation and Final Commitments" in Kaj Hobér, Anna Jonsson Cornell, and Leonis Polishchuck (eds), The Uppsala Yearbook of Eurasian Studies: Volume I (Wildy, Simmonds \& Hill, London, 2016) 64.

107 See Azaria, op.cit. note 77, 32 and 35 .

108 Dralle, op.cit. note $3_{2} 274-275$.

109 Ibid., 275; Simonetta Zarrilli, "Multilateral Rules and Trade in Energy Goods and Services: The Case of Electricity" in Janusz Bielicki and Melaku Geboye Desta (eds), Electricity Trade in Europe - Review of the Economic and Regulatory Changes (Kluwer, The Hague, 2004) 249-250; WTO, Council for Trade in Services, Energy Services - Background Note, op.cit. note 104 , paras $40-41$.

110 Dralle, op.cit. note $\xi_{2} 275$.
} 
Gazprom. Beyond that, the common opinion appears to be that the GATs does not regulate vertically integrated gas producers and suppliers such as Gazprom via the Nord Stream 2 network, ${ }^{111}$ in particular if such a gas producer does not charge separately for gas shipment services. The price formulae for gas shipments by Gazprom do not appear to mention transportation costs, ${ }^{112}$ which, eventually, makes the applicability of the GATs to Nord Stream 2 even more implausible.

In conclusion, this means that the GATs cannot guarantee third-party access and unbundling requirements in the context of Nord Stream 2.

\section{$3 \cdot 3$ \\ The Law of the Sea and Possible Indirect Application of EU Law \\ 3.3.1 Preliminary Considerations of Territorial Jurisdiction in the Law of the Sea}

In the previous sections, I concluded that the strict requirements of EU law namely, third-party access and unbundling - cannot be guaranteed by either the relevant provisions of the Energy Charter Treaty or by those of the WTO agreements in order to assure solidarity in EU energy law. The last option I examine in this paper is a possible indirect application of EU law and the Third Gas Directive through international law, namely the law of the sea and its rules on territorial jurisdiction. This might be possible because Nord Stream 2 will run along more or less the same route as Nord Stream 1, that is, first through Russian territorial waters and the Russian exclusive economic zone; and then through the Finnish and Swedish exclusive economic zones. Lastly, the pipeline will then proceed through both the Danish and German exclusive economic zones as well as the Danish and German territorial seas, eventually making landfall after crossing German internal waters at Greifswald on the German coast. ${ }^{113}$ Moreover, no bespoke pipeline agreement was concluded for Nord Stream 1, which was consequently constructed by applying the relevant rules of the law of the sea, ${ }^{114}$ in particular Article 58(1) of the United Nations Convention on the Law of the Sea (UNCLOS) and the freedom to lay submarine

\footnotetext{
111 Irina Musselli and Simonetta Zarrilli, "Oil and Gas Services: Market Liberalization and the Ongoing GATs Negotiations”, 8(2) Journal of International Economic Law (2005), 551-581, at 562; Mireille Cossy, "Energy Services under the General Agreement on Trade in Services" in Yulia Selivanova (ed), Regulation of Energy in International Trade Law: WTO, NAFTA, and Energy Charter (Kluwer, Aalphen aan den Rjin, 2011) 161.

112 Pogoretskyy, op.cit. note $70,174-175$.

113 Riley, op.cit. note $¥ 4,3$.

114 Azaria, op.cit. note 77, 51.
} 
pipelines in the exclusive economic zone, reflecting customary international law. ${ }^{115}$

The question is whether the same is now true for Nord Stream 2 as well, and why and how the law of the sea could apply to it in order to guarantee the requirements of unbundling and third-party access. Of course, the law of the sea does not in itself regulate these requirements, as they are not covered by the subject-matter of this legal regime. Yet perhaps a different solution may be possible: in line with the principle that 'the land dominates the sea', meaning that maritime rights derive from a State's sovereignty over the land, ${ }^{116}$ it could therefore be argued that EU law may apply through the prism of its Member States' territorial jurisdiction over their respective internal as well as territorial waters and exclusive economic zones. All of the abovementioned States - Finland, Sweden, Denmark, and Germany - are EU Member States. Thus, the unbundling and third-party access requirements enshrined in EU law could apply indirectly qua the general rules of the law of the sea on maritime delimitation, piggybacking on this vehicle to application at least within the waters of EU Member States which are all, plus the EU itself, contracting parties to the Convention. ${ }^{117}$ The problem with this possible solution is, however, that it results - in contrast to WTO law - in the unilateral application of a specific legal regime (in this case EU law, that is, the domestic law of one of the parties involved) to only certain parts of the pipeline. It does not necessarily result in a conflict of laws, as EU law would definitely not apply to those parts of the Nord Stream 2 pipeline located in Russian waters. However, this solution - even though it could at least partially guarantee the requirements of EU energy law would be far from ideal: legally speaking, these requirements would only cover certain parts of the pipeline; politically speaking, the unilateral application of

115 Robin Churchill and Vaughan Lowe, The Law of the Sea ( $3^{\text {rd }}$ edn; Manchester University Press, Manchester, 1999) 161-162; Military and Paramilitary Activities in and against Nicaragua (Nicaragua v United States of America) (Merits) [1986] ICJ Rep. 14, para 214.

116 See, eg, Grisbadarna Case (Norway, Sweden), Arbitral Award of 23 October 1909, RIAA XI, 155, at 159; North Sea Continental Shelf Cases Germany v Denmark; Germany v Netherlands) [1969] ICJ Rep. 3, para 96; Aegean Sea Continental Shelf (Greece v Turkey) [1978] ICJ Rep. 3, para 86; Maritime Delimitation and Territorial Questions between Qatar and Bahrain (Qatarv Bahrain) [2001] ICJ Rep. 97, para 185; Delimitation of the Maritime Boundary between Bangladesh and Myanmar in the Bay of Bengal [2012] ITLOs Rep. 4, para 185. See also Bing Bing Jia, "The Principle of the Domination of the Land over the Sea: A Historical Perspective on the Adaptability of the Law of the Sea to New Challenges", 57 German Yearbook of International Law (2014), 63-93.

117 See also Esa Paasivirta, "The European Union and the United Nations Convention on the Law of the Sea", 38(4) Fordham International Law Journal (2015), 1045-1071. 
EU law - albeit legally permissible - could be seen by Russia as undermining the effectiveness of the common project. ${ }^{118}$

In this section, I will now investigate whether EU law may apply through the law of the sea to Nord Stream 2 or not.

3.3.2 Applicability of EU Law in the Territorial Sea of the Member States The argument that EU law is not applicable to the Nord Stream 2 pipeline at all is difficult to sustain, seeing that it will run through considerable portions of Danish and German territorial waters, plus a further stretch of German internal waters. ${ }^{119}$ Articles 2 and 3 UNCLOS state that the sovereignty of the coastal State extends beyond its land territory and internal waters to the territorial sea, which can then stretch out up to 12 nautical miles from the respective State's baselines. This is the case for both Denmark and Germany, which have extended their territorial waters to the 12 nautical mile limit. ${ }^{120}$ Furthermore, given the decisions of the Court of Justice of the EU (CJEU) in the Kramer and Poulsen cases, it is now evident that the EU's territorial jurisdiction is congruent with that of the Member States, and that accordingly, Union law applies in their internal waters and territorial sea. ${ }^{121}$

This means, in conclusion, that at least within the internal waters and territorial sea of Union Member States, EU energy law - including the Third Gas Directive and its requirements - would apply, even to external pipelines such as Nord Stream 2, bringing gas to the Union's internal gas market. ${ }^{122}$

\subsubsection{Applicability of EU Law in the Exclusive Economic Zone and Continental Shelf of the Member States}

The application of EU energy law to those parts of the Nord Stream 2 pipeline running through the territorial and internal waters of EU Member States is a

118 Although this reaction would be grist to the mill of the sceptics and critics of Nord Stream 2 , as it would suggest that Russia is pursuing a geopolitical agenda in this matter and that the application of EU energy law, ensuring certain competition standards, would constitute an obstacle to that goal.

119 Riley, op.cit. note $¥ 4$. 3 .

120 For Denmark, see Act No. 200 of 7 April 1999 on the Delimitation of the Territorial Sea; for Germany, see M.Z.N. 1. 1995. LOS (Maritime Zone Notification) of 8 March 1995, Deposit by the Federal Republic of Germany of charts and geographical coordinates on the territorial sea and the exclusive economic zone in the Baltic Sea and in the North Sea, and Proclamation of 11 November 1994 by the Government of the Federal Republic of Germany concerning the Extension of the Breadth of the German Territorial Sea.

121 Joined Cases 3/76, 4/76, and 6/76 Kramer [1976] ECR 1279; Case C-286/9o Poulsen [1992] ECR I-6019, paras 28-34. See also Arts 52 TEU and 355 TFEU.

122 Riley, op.cit. note \% $_{2}$; Talus and Wüstenberg, op.cit. note 143. 
good start, but it does not answer the additional question whether EU law can also be applied in the respective exclusive economic zones of these States. If the answer is in the affirmative, this would make for an even stronger case in favor of the solidarity requirements of the Third Gas Directive.

To begin with, it needs to be emphasized that in the exclusive economic zone, extending to 200 nautical miles from the baselines from which the breadth of the territorial sea is measured, the coastal State does not enjoy territorial sovereignty, but merely certain sovereign rights over economic resources located within it. ${ }^{123}$ This functional sovereignty over the exclusive economic zone, limited by the relevant provisions of the Convention, was also acknowledged by the CJEU in Aktiebolaget by reiterating that Articles 56 and 77 UNCLOS only provide for the coastal State's sovereign right to explore and exploit the natural resources of its exclusive economic zone and continental shelf. However, the freedom to lay submarine pipelines in the exclusive economic zone, enshrined in Articles 58(1) and 79(1) UNCLOs is not a sovereign right and also open to other States, subject to certain conditions. ${ }^{124}$

Thus, the question is whether and how a coastal State's law (in this case also EU law) can apply to pipelines constructed in its exclusive economic zone. Articles 6o(2) and 80 UNCLOS clearly give the coastal State exclusive jurisdiction over infrastructures established in the exclusive economic zone and on the continental shelf, such as artificial islands and installations as well as structures for economic purposes and for exploring as well as exploiting natural resources, regarding customs, fiscal, health, safety, and immigration laws and regulations. Hence, the coastal State can indeed apply its domestic law to regulate their operation. ${ }^{125}$ This also includes EU law, as the CJEU has confirmed in two cases. In the 2002 Weber case, for instance, it held that work carried out by an employee on an oil platform located on the Netherlands' section of the continental shelf was subject to the relevant rules of Union law. ${ }^{126}$ This approach

123 Arts 55-58 UnClos. See also Umberto Leanza and Maria Cristina Caracciolo, "The Exclusive Economic Zone" in David Joseph Attard, Malgosia Fitzmaurice, and Norman A Martínez Gutiérrez (eds), The IMLI Manual on International Maritime Law - Volume I: The Law of the Sea (OuP, Oxford, 2014) 185-186; Alexander Proelss, "Article 55" in Alexander Proelss (ed), United Nations Convention on the Law of the Sea: A Commentary (CH Beck, Munich, 2017) paras $15^{-18 .}$

124 Case C-111/05 Aktiebolaget NN [2007] ECR I-2697, para 59.

125 Riley, op.cit. note 34 , 4.

126 Case C-37/oo Weber [2002] ECR I-2013, para 31. See also Pieter Jan Kuijper, "Customary International Law, Decisions of International Organizations and other Techniques for Ensuring Respect for International Legal Rules in European Community Law", in Jan Wouters, André Nollkaemper, and Erika de Wet (eds), The Europeanization of International 
was later confirmed in the 2012 Salemink judgment, which even more forcefully pronounced that a Member State taking advantage of the economic rights to prospect or exploit natural resources on the continental shelf "cannot avoid the application of the EU law provisions designed to ensure the freedom of movement of persons working" on its installations there. ${ }^{127}$

At the same time, the situation concerning pipelines running through a coastal State's exclusive economic zone is less clear. One could argue that they are also installations and structures within the meaning of Articles 6o(2) and 80 UNCLOS and that they are consequently also subject to the domestic law of the coastal State (plus EU law, if that coastal State is an EU Member State). The difficulty with this argument is that Articles 58(1) and 79(4) UNCLOS plainly differentiate between installations and structures to which the domestic law of the coastal State can apply, on the one hand, and pipelines and cables to which a more limited domestic legal regime applies, on the other. ${ }^{128}$ As already mentioned above, Articles 58(1) and 79(1) UNCLOS set forth the freedom of all States to lay submarine cables and pipelines in the exclusive economic zone and the continental shelf, respectively. These provisions need to be read in conjunction with Articles 56(2) and 79(2) UNCLOS, providing that a coastal State in its exclusive economic zone "shall have due regard to the rights and duties of other States and shall act in a manner compatible with the provisions of this Convention", nor may it "impede the laying or maintenance of such cables and pipelines." This means that the Convention offers no legal grounds on which an outright prohibition of laying cables or pipelines within the exclusive economic zone or on the continental shelf of another State could be based. ${ }^{129}$

Nevertheless, this does not leave the coastal State without any rights concerning pipeline projects in their exclusive economic zone and continental shelf. It is of course true that Articles 58(1) and 79(1) UNCLOS provide all States with a right to lay pipelines and cables in the exclusive economic zone and on the continental shelf of the coastal State concerned, but Articles 56(1)(b) (iii) and 79(2) UNCLOS also require all States to protect and preserve the marine environment as well as to prevent, reduce, and control pollution from

Law: The Status of International Law in the EU and Its Member States (TмC Asser Press, The Hague, 2008) 92.

127 Case C-347/10 Salemink [2012] ECLI:EU:C:2012:17, para 36.

128 Riley, op.cit. note $34,4$.

129 Talus and Wüstenberg, op.cit. note 4 , 143; Catherine Redgwell, "Contractual and Treaty Arrangements Supporting Large European Transboundary Pipeline Projects: Can Adequate Human Rights and Environmental Protection Be Secured?" in Martha M Roggenkamp, Lila Barrera-Hernández, Donald N Zillman, and Iñigo del Guayo (eds), Energy Networks and the Law: Innovative Solutions in Changing Markets (OUP, Oxford, 2012) 112. 
pipelines. ${ }^{130}$ This means that the coastal State can certainly impose obligations on other States that construct submarine pipelines in their exclusive economic zone and continental shelf, at least in relation to environmental matters. And although, according to Article 79(2) UNCLOS, the coastal State may nonetheless not impede the laying or maintenance of cables and pipelines, the CJEU could be distinctly sympathetic towards permitting the application of EU law to pipelines in the exclusive economic zone of the affected Member States. In the Habitats Directive case of 2005, the CJEU highlighted that the Member States are obliged to apply EU law beyond their territorial waters and in their exclusive economic zone in order to guarantee its effectiveness. ${ }^{131}$ Admittedly, both the cited Convention provisions and this case are concerned with protection of the marine environment, and not with requirements such as thirdparty access and unbundling, but from the CJEU's 'effectiveness argument' in environmental law, ${ }^{132}$ it is only a short step to applying the same reasoning to the EU's energy regime. With reference to the argument that in order for EU law to be fully effective, it also needs to be applied beyond the territorial sea - a teleological approach the Court also pursued in the abovementioned Kramer case $^{133}$ - one could argue that the same is true of EU energy law, so that to fail to apply the Gas Directive in the exclusive economic zone and on the continental shelf of the Member States would seriously undermine the uniform application of the EU's liberalization program for the gas market as well as open up the potential for evasion of this program by market participants. The main element of this line of reasoning is that if EU law in general and the Third Gas Directive in particular did not apply to the offshore parts of Nord Stream 2 located in the exclusive economic zone and on the continental shelf of the Member States concerned, then the objectives of this directive would be considerably weakened as follows: by applying EU law solely to those areas where the coastal State enjoys full territorial sovereignty (that is, its land territory, internal waters, and territorial sea), full liberalization of the EU energy market would not be fully achievable, as major parts of the Nord Stream 2 infrastructure would remain subject to the control of powerful market players that

\footnotetext{
130 These provisions are complemented by the general obligation to protect and preserve the marine environment (Art 192 UNCLOS) and to take measures to prevent, reduce, and control pollution of the marine environment from any source (Art 194(1) UNCLOS).

131 Case C-6/04 Commission v United Kingdom (Habitats Directive) [2005] ECR I-9017, paras $115^{-117}$.

132 See Case C-6/o4 Commission v United Kingdom (Habitats Directive) [2005] EC R I-9017, Opinion of Advocate General Kokott, paras 132-133.

133 Joined Cases 3/76, 4/76, and 6/76 Kramer [1976] ECR 1279.
} 
would thus be able to control both the pipelines and the gas supply. Moreover, the non-application of EU law to these parts would have the effect of creating extremely distorting incentives to build additional infrastructure in the sea and beyond the control of the coastal State, hence further undermining market liberalization. Lastly, the relevant Convention provisions do not take into account other legitimate interests of the coastal State that could be engaged as a result of pipelines being constructed, for instance, broader health and safety concerns, security, or economic regulation. ${ }^{134}$

Possible application of EU law is also supported by considering Article 56(2) UNCLOS, requiring a balancing of the interests of both the coastal State and other States. ${ }^{135}$ Interpretation of this provision by international courts and tribunals has shown that the history and rationale of the regime of the exclusive economic zone arguably militates in support of accepting a shift of emphasis in favor of the coastal State. ${ }^{136}$ First, it should be recalled that the notion of 'sovereign rights' constitutes an extract from the broader concept of 'sovereignty', and when also taking into account the functional status of the exclusive economic zone, it appears to be difficult to uphold the argument that the coastal State cannot be seen as being somehow privileged regarding the rights and jurisdiction referred to in Article 56(1) UNCLOS. The opposite view would, for example, render marine spatial planning in the exclusive economic zone unlawful, which would ignore recent developments in State practice. Marine spatial planning is a tool to avoid conflicts between different rights and interests of States operating in the exclusive economic zone from the outset, and can only be used as an extract from the coastal State's sovereign rights and jurisdiction therein. ${ }^{137}$ The mere fact that Article $5^{6}$ UnCLOS in particular or the Convention in general remain silent on marine spatial planning as a management process ${ }^{138}$ does not imply that the process concerned is not covered

\footnotetext{
134 Riley, op.cit. note 34,5 .

135 Permanent Court of Arbitration, Chagos Marine Protected Area Arbitration (Mauritius $v$ United Kingdom), Award of 18 March 2015, para 534; Ishrak Ahmed Siddiky, "The International Legal Instruments for Cross-Border Pipelines" in Kim Talus (ed), Research Handbook on International Energy Law (Edward Elgar, Cheltenham, 2014) 311.

136 David J Attard, The Exclusive Economic Zone in International Law (Clarendon Press, Oxford, 1987) 75; Alexander Proelss, "Article 56" in Alexander Proelss (ed), United Nations Convention on the Law of the Sea: A Commentary (CH Beck, Munich, 2017) paras 25-26.

137 Ibid., para 27.

138 Frank Maes, "The International Legal Framework for Marine Spatial Planning", 32(5) Marine Policy (2008), 797-810, at 799 .
} 
by the Convention provisions. ${ }^{139}$ The same could be argued in favor of the applicability of EU energy law.

Conversely, as far as the rights of other States are concerned, Article 58(1) UNCLOS does not mention 'sovereign rights', but simply 'freedoms'. These freedoms refer to the regime of the high seas, but it is vital to note that Article 87 UNCLOS, enshrining all specific types of freedom of the high seas, cannot be applied to the exclusive economic zone in an unmodified manner. In fact, Article 58(1) UNCLOS subjects the exercise of 'the freedoms referred to in Article $87[\ldots]$ of the laying of submarine cables and pipelines [...] to the relevant provisions of this Convention.' The exercise of the freedoms mentioned in Article 58(1) UNCLOS is therefore - compared to the high seas - subjected to stricter limits in the exclusive economic zone. ${ }^{140}$ As a practical approach to resolving potential conflicts in a flexible manner, a rebuttable presumption in favor of the coastal State has been suggested, a presumption which can only be activated if the coastal State's behavior does not amount to an abuse of rights. ${ }^{141}$ Seeing that the due regard rule in Article $56(2)$ UNCLOS does not distinguish between 'sovereign rights' and 'jurisdiction', it could accordingly be argued that the shift of emphasis in favor of the coastal State advocated here should also apply in respect of the coastal State's jurisdiction in terms of Article 56(1)(b)(iii) UNCLOS, that is, the protection and preservation of the marine environment. ${ }^{142}$ In the present context, one should therefore not distinguish between these two categories of 'sovereign rights' and 'jurisdiction', as this would disregard the suigeneris status of the exclusive economic zone as being characterized by both categories. A fortiori, the term 'jurisdiction' as codified in Article 56(1)(b)(iii) UNCLOs should be regarded as a proxy for the further development and substantiation of other rights of the coastal State, as long as the Convention does not contain any special rules to the contrary. ${ }^{143}$ Hence, seeing that this is not the case with respect to energy law, there is no reason why EU energy law should not be extended to the exclusive economic zone of the EU Member States concerned. In this case, the unbundling and

139 Mathias Schubert, Maritimes Infrastrukturrecht (Mohr Siebeck, Tübingen, 2015) 59-62.

140 Proelss, "Article 56", op.cit. note ${ }_{35}$, para 28; Edward D Brown, "The Exclusive Economic Zone: Criteria and Machinery for the Resolution of International Conflicts between Different Users of the EEz", 4(6) Maritime Policy and Management, 325-350, at 337; Maria Gavouneli, Functional Jurisdiction in the Law of the Sea (Martinus Nijhoff, Leiden, 2007) 65 et seq.

141 Proelss, "Article 56", op.cit. note 135 para 29.

142 Alexander Proelss, "The Law on the Exclusive Economic Zone in Perspective: Legal Status and Resolution of User Conflicts Revisited", 26(1) Ocean Yearbook(2012), 87-112, 102 et seq.

143 Ibid., 104 et seq., Proelss, "Article 56", op.cit. note ${ }_{35}$ para 30. 
third-party access requirements can be guaranteed, albeit indirectly qua the law of the sea, in the context of Nord Stream 2.

\section{$4 \quad$ Conclusion}

The plan of this paper was to describe, illustrate, and examine which legal regime will apply to Nord Stream 2, and whether that legal regime will be able to guarantee the same requirements as EU energy law to safeguard solidarity among the EU Member States, first and foremost third-party access and unbundling. This question is of extreme significance until the entry into force of an amendment to the Third Gas Directive, which should then ensure the application of EU law and these requirements to the Nord Stream 2 pipeline.

Until then, these requirements cannot be guaranteed through either the Energy Charter Treaty or the relevant wTO agreements, in the shape of the GATT and the GATS. It might be politically inappropriate to apply EU law indirectly through the relevant jurisdictional provisions of the Law of the Sea Convention, but in my view, this is - again, until an amended Gas Directive enters into force and thereby guarantees the application of Union law to Nord Stream 2 - the only way to make sure that fair competition rules are at work and that this pipeline project is not abused for geopolitical reasons and to undermine EU policy, especially in Eastern Europe and in Ukraine. ${ }^{144}$ There is no doubt that EU law applies in the respective internal waters and territorial seas of the Member States concerned, but I also think that application in the exclusive economic zones of other Member States is also highly probable and can be argued on the basis of lex lata. This would, at least, provide for a greater territorial scope of application of EU law in the Baltic Sea and thus also allow for a higher degree of fair market competition and energy solidarity.

144 Riley, op.cit. note $3_{2} 25$. 